\title{
The association of angiotensin-converting enzyme with biomarkers for Alzheimer's disease
}

\author{
Hadassa M Jochemsen ${ }^{1,2}$, Charlotte E Teunissen ${ }^{3}$, Emma L Ashby ${ }^{4}$, Wiesje M van der Flier ${ }^{1}$, Ruth E Jones ${ }^{4}$, \\ Mirjam I Geerlings ${ }^{2}$, Philip Scheltens ${ }^{1}$, Patrick G Kehoe ${ }^{4^{*}}$ and Majon Muller ${ }^{5^{*}}$
}

\begin{abstract}
Introduction: Lower angiotensin-converting enzyme (ACE) activity could increase the risk of Alzheimer's disease $(A D)$ as ACE functions to degrade amyloid- $\beta$ (A $\beta$ ). Therefore, we investigated whether ACE protein and activity levels in cerebrospinal fluid (CSF) and serum were associated with CSF A $\beta$, total tau (tau) and tau phosphorylated at threonine 181 (ptau).

Methods: We included 118 subjects from our memory clinic-based Amsterdam Dementia Cohort (mean age $66 \pm 8$ years) with subjective memory complaints $(n=40)$ or $A D(n=78)$, who did not use antihypertensive drugs. We measured ACE protein levels (ng/ml) and activity (RFU) in CSF and serum, and amyloid $\beta_{1-42}$, tau and ptau (pg/ml) in CSF.

Results: Cross-sectional regression analyses showed that ACE protein level and activity in CSF and serum were lower in patients with AD compared to controls. Lower CSF ACE protein level, and to a lesser extent serum ACE protein level and CSF ACE activity, were associated with lower CSF A $\beta$, indicating more brain A $\beta$ pathology; adjusted regression coefficients (B) $(95 \%$ Cl) per SD increase were $0.09(0.04 ; 0.15), 0.06(0.00 ; 0.12)$ and $0.05(0.00 ; 0.11)$, respectively. Further, lower CSF ACE protein level was associated with lower CSF tau and ptau levels; adjusted B's ( $95 \% \mathrm{Cl}$ ) per SD increase were 0.15 $(0.06 ; 0.25)$ and $0.17(0.10 ; 0.25)$, respectively.
\end{abstract}

Conclusions: These results strengthen the hypothesis that ACE degrades A by for example ACE-inhibitors might have adverse consequences for patients with, or at risk for AD.

\section{Introduction}

Alzheimer's disease (AD) is characterized by the accumulation of extracellular amyloid-beta $(\mathrm{A} \beta)$ plaques and intracellular neurofibrillary tangles (tau pathology), which are reflected by lower $A \beta$, and higher total tau (tau) and tau phosphorylated at threonine 181 (ptau) in cerebrospinal fluid (CSF) [1].

In the last decade, the role of the renin-angiotensin system (RAS) in the etiology of $\mathrm{AD}$ has received increasing attention. Inheritance of the I-allele - associated with lower plasma angiotensin-converting enzyme (ACE) levels [2] - was related to increased risk of AD [3,4], although these findings have not been supported by recent genomewide association studies [5,6] and large haplotype studies

\footnotetext{
* Correspondence: patrick.kehoe@bristol.ac.uk; m.muller@lumc.nl ${ }^{4}$ Dementia Research Group, Institute of Clinical Neurosciences, School of Clinical Sciences, University of Bristol, Frenchay Hospital, Bristol BS16 1LE, UK ${ }^{5}$ Department of Gerontology and Geriatric Medicine, Leiden University Medical Center, Leiden, The Netherlands

Full list of author information is available at the end of the article
}

[7]. Further, in vitro studies showed that ACE functions to degrade $A \beta$, and administration of ACE inhibitors promoted the accumulation of $A \beta$ [8-10], while in vivo studies on various mouse models of $\mathrm{AD}$ showed indirect evidence that ACE can degrade $A \beta$ (reviewed in [11]). Together, these data suggest that ACE is important for $A \beta$ degradation, and hence low ACE activity can lead to increased $A \beta$-mediated neuronal damage, plaque accumulation, and risk of $\mathrm{AD}$ [12].

Few studies have examined the association between ACE and AD biomarkers in CSF [13,14]. Results on the association between the I-allele, or haplotypes, of the $A C E$ gene, which have been associated with lower ACE levels, and CSF A $\beta$ were inconclusive $[13,14]$. Further, one smallscale study found that administration of an ACE inhibitor did not influence AD biomarkers in CSF [15].

The current literature almost entirely comes from laboratory-based and genetic association studies. However, the laboratory-based studies are not comparable with the human disease state and the findings from 
genetic-association studies may be explained by linkage disequilibrium with the true risk factor [3]. Examining direct measures of ACE (such as serum or CSF ACE) in relation to CSF AD biomarkers might therefore be more clinically meaningful - especially since the widely prescribed antihypertensive ACE-inhibitors strongly inhibit ACE activity [16], thereby possibly not only reducing the unfavorable angiotensin (ANG)I to ANGII conversion, but also the favorable $A \beta$ degradation.

The aim of the current study was to investigate the association of serum and CSF ACE protein levels and activity with CSF AD biomarkers - A $\beta$, tau and ptau in a memory clinic cohort. It has increasingly been recognized that nearly all organs of the body have their own local paracrine-like RAS, with organ-specific functions [17]. The brain also has its own RAS system, acting largely independent of the peripheral RAS [17]. We therefore hypothesize that CSF and serum ACE reflect the activity in the brain RAS and peripheral RAS, respectively, and that CSF ACE activity and, to a lesser extent, serum ACE activity are associated with lower CSF A $\beta$, indicating worse $A \beta$-related pathology in the brain.

\section{Methods}

\section{Study population}

Patients were included from the memory clinic-based Amsterdam Dementia Cohort of the Alzheimer Center of the VU University Medical Center (VUMC). They underwent standard dementia screening including physical and neurological examination, as well as laboratory tests, electroencephalography, brain magnetic resonance imaging and comprehensive neuropsychological testing. The diagnosis of probable AD was made according to the National Institute of Neurological Disorders and StrokeAlzheimer's Disease and Related Disorders Association criteria [18] by consensus of a multidisciplinary team, without knowledge of CSF results and the apolipoprotein $\mathrm{E}(A P O E)$ genotype. When the results of all examinations were normal, patients were considered to have subjective complaints (that is, criteria for mild cognitive impairment not fulfilled). Diabetes mellitus and hypercholesterolemia were defined based on self-reported medical history and medication use. Blood pressure was measured manually in a standardized manner using a sphygmomanometer with the patient in a sitting position after 5 minutes of rest. The level of education was classified using the seven-point rating scale of Verhage ranging from 1 (low, elementary school not completed) to 7 (high, university).

For the current study, patients using antihypertensive drugs were excluded, because some of these drugs strongly influence ACE levels [19]. Of the patients aged 50 to 80 years old with available CSF, we included 40 persons with subjective complaints (control group) and 78 persons with AD (AD group). The ethical review board of the
VUMC approved the study and all subjects gave written informed consent.

\section{Sampling of blood and cerebrospinal fluid}

A blood sample was taken, and after half an hour of clotting the samples were spun at $1,800 \times g$ for 10 minutes at $4^{\circ} \mathrm{C}$, then aliquoted into Sarstedt polypropylene cryovials and immediately stored at $-80^{\circ} \mathrm{C}$ until further analyses. CSF was obtained by lumbar puncture between the L3/L4 or the L4/L5 intervertebral space, using a 25-gauge needle, and collected in $10 \mathrm{ml}$ polypropylene tubes. Within two hours, $2 \mathrm{ml}$ of CSF samples were centrifuged at $1,800 \times g$ for 10 minutes at $4^{\circ} \mathrm{C}$ and stored at $-20^{\circ} \mathrm{C}$ for analysis of CSF biomarkers within 2 months (see below). The remainder of the CSF was aliquoted in polypropylene tubes of 0.5 or $1 \mathrm{ml}$, and stored at $-80^{\circ} \mathrm{C}$ until further analysis [20].

\section{$A P O E$ and Alzheimer's disease cerebrospinal fluid biomarkers}

DNA was isolated from $10 \mathrm{ml}$ ethylenediamine tetraacetic acid blood and the $A P O E$ genotype was determined using the Light Cycler $A P O E$ mutation detection method (Roche Diagnostics GmbH, Mannheim, Germany).

CSF $A \beta_{1-42}$, tau, and ptau were measured by commercially available ELISAs (Innotest $-\beta$-amyloid $(1-42)$, Innotest hTAU-Ag 168 and Innotest Phosphotau $(181 \mathrm{P})$; Innogenetics, Ghent, 169 Belgium). The performance of the assays was monitored with internal quality controls consisting of pools of surplus CSF specimens. In the study period, multiple internal quality controls with various concentrations have been used. The interassay coefficient of variation $(\mathrm{CV})$ (mean \pm standard deviation) was $11.3 \pm 4.9 \%$ for $\mathrm{A} \beta, 9.3 \pm$ $1.5 \%$ for tau, and $9.4 \pm 2.5 \%$ for ptau [21]

\section{Angiotensin-converting enzyme protein assays}

A commercially available sandwich enzyme-linked immunosorbent assay (R\&D Systems, Abingdon, UK) was used according to the manufacturer's guidelines to measure the ACE concentration in CSF and serum, as described previously [22]. Absorbance was read at $450 \mathrm{~nm}$ on a FLUOstar OPTIMA plate reader (BMG Labtech, Aylesbury, Buckinghamshire, UK). The samples were analyzed in duplicate, and ACE concentrations were interpolated from the standard curves of known concentrations of recombinant human ACE (929-ZN; R\&D Systems). The ACE inhibitor captopril was purchased from Enzo Life Sciences (Exeter, UK). The interassay CV (mean \pm standard deviation) was $8.7 \pm 8.9 \%$ for CSF ACE and $13.0 \pm 7.0 \%$ for serum ACE. The intraassay CV was $7.9 \pm 6.5 \%$ for CSF ACE and $7.6 \pm 5.6 \%$ for serum ACE.

\section{Angiotensin-converting enzyme activity assays}

Monoclonal anti-human ACE antibody (MAB929), recombinant human ACE $(929-\mathrm{ZN})$ and the internally 
quenched fluorogenic peptide substrate (Mca-RPPGFSAFK (Dnp)-OH; ES005) were purchased from R\&D Systems and were used to optimize an immunocapture-based fluorogenic assay for measurement of ACE activity in CSF and serum (see also Additional file 1) based on the method previously used by Miners and colleagues [23]. Fluorescence was measured by excitation at $320 \mathrm{~nm}$ and emission at $405 \mathrm{~nm}$, in a FLUOstar OPTIMA plate reader. The mean fluorescence of the negative controls was subtracted from standard and sample readings, as was done for the fluorescence of the ACE-specific captoprilinhibited well. The ACE-specific inhibitor captopril inhibited ACE activity by more than $90 \%$. Each sample was measured in duplicate and the mean fluorescence of $\mathrm{ACE}$ activity was calculated, based on the standard curve of recombinant ACE. The interassay CV (mean \pm standard deviation) was $8.5 \pm 8.4 \%$ for CSF ACE and $8.1 \pm 8.7 \%$ for serum ACE. The intra-assay CV was $8.7 \pm 5.9 \%$ for CSF $\mathrm{ACE}$ and $9.1 \pm 8.5 \%$ for serum ACE.

\section{Data analyses}

We used multiple imputation (10 datasets) to address missing values (see Table 1), and data were analyzed using SPSS version 20.0 (Chicago, IL, USA), by pooling the 10 imputed datasets [24,25].

First, patient characteristics were calculated for separate study groups (control group and AD group) and differences were evaluated by analysis of variance for continuous variables, or by Fisher's exact test for categorical variables. Second, Pearson's correlation coefficients between ACE protein and activity levels for each of CSF and serum in turn were examined. Pearson's correlation coefficients between $A \beta$ and tau or ptau were also analyzed. Third, we examined the linear regression between $A P O E-\varepsilon 4$ allele and $A \beta$, tau and ptau (Model 2). Fourth, linear regression analysis was used to investigate the associations of ACE measures (continuous) with logtransformed CSF biomarker levels of $A \beta$, tau and ptau (continuous), unadjusted (Model 1) and adjusted for age, sex and study groups (Model 2). Since inheritance of the $\mathrm{AD}$ risk-associated $A P O E$ - $\varepsilon 4$ allele and vascular risk factors including blood pressure measures could influence the association between ACE measures and CSF biomarkers, we additionally adjusted for $A P O E-\varepsilon 4$ (carrier vs. noncarrier) and vascular risk factors (systolic blood pressure, diastolic blood pressure, body mass index, smoking, history of hypercholesterolemia or diabetes mellitus) (Model 3). Finally, analysis of covariance was used to estimate the adjusted mean log-transformed CSF $A \beta$, tau and ptau levels across tertiles of ACE measures within the separate study groups. For graphical purposes, the log-transformed values were back transformed.
Table 1 Baseline characteristics for the separate study groups after imputation

\begin{tabular}{|c|c|c|}
\hline & $\begin{array}{l}\text { Control group } \\
(n=40)\end{array}$ & $\begin{array}{c}\text { AD group } \\
(n=78)\end{array}$ \\
\hline \multicolumn{3}{|l|}{ Demographics } \\
\hline Age (years) & $63(8)$ & $68(7)^{* *}$ \\
\hline Female sex (\%) & 47 & $64^{*}$ \\
\hline Education (range 1 to 7 ) & 6 (3 to 7$)$ & 5 (3 to 6) \\
\hline APOE-ع4 carrier (\%) & 23 & $66^{*}$ \\
\hline MMSE (range 0 to 30) & 28 (26 to 30$)$ & $22(16 \text { to } 27)^{*}$ \\
\hline \multicolumn{3}{|l|}{ Vascular risk factors/disease } \\
\hline Smoking (\% current) & 23 & 23 \\
\hline Body mass index $\left(\mathrm{kg} / \mathrm{m}^{2}\right)$ & $25(5)$ & $24(5)$ \\
\hline Diabetes mellitus (\%) & 14 & 14 \\
\hline Hypercholesterolemia (\%) & 28 & $22^{*}$ \\
\hline \multicolumn{3}{|l|}{ Blood pressure measures } \\
\hline Systolic (mmHg) & $133(14)$ & $147(22)^{* *}$ \\
\hline Diastolic (mmHg) & $83(9)$ & $86(13)^{* *}$ \\
\hline Hypertension (\%) & 30 & $55^{*}$ \\
\hline \multicolumn{3}{|l|}{ ACE measures } \\
\hline CSF ACE protein level (ng/ml) & $3.78(1.30)$ & $3.56(1.16)^{* *}$ \\
\hline CSF ACE activity (RFU) & $155(61)$ & $148(58)^{*}$ \\
\hline Serum ACE protein level ( $\mathrm{ng} / \mathrm{ml})$ & $4.22(1.50)$ & $3.72(1.14)^{* *}$ \\
\hline Serum ACE activity (RFU) & $255(152)$ & $205(116)^{* *}$ \\
\hline \multicolumn{3}{|l|}{ CSF biomarkers } \\
\hline Amyloid $\beta_{1-42}(\mathrm{pg} / \mathrm{ml})$ & $\begin{array}{l}887(622 \\
\text { to } 1,157)\end{array}$ & $475(334 \text { to } 743)^{* *}$ \\
\hline Total tau $(\mathrm{pg} / \mathrm{ml})$ & 246 (122 to 371$)$ & $619(344 \text { to } 1,102)^{* *}$ \\
\hline Phosphorylated tau (pg/ml) & 45 (29 to 74$)$ & $87(54 \text { to } 137)^{* *}$ \\
\hline
\end{tabular}

Data presented as mean (standard deviation), percentage, or median (10th to 90th percentile). Percentage of missing values before imputation: education, $0.8 \%$; APOE genotyping, serum ACE protein and activity levels, $1.7 \%$; MMSE, $3.4 \%$; smoking, $7.6 \%$; diabetes mellitus and hypercholesterolemia, $14 \%$; all other variables, $0 \%$. ACE, angiotensin-converting enzyme; $A D$, Alzheimer's disease; APOE, apolipoprotein E; CSF, cerebrospinal fluid; MMSE: Mini-Mental State Examination; RFU, relative fluorescence units.

${ }^{*} P<0.05$ versus controls, ${ }^{*} P<0.01$ versus controls.

\section{Results}

In the total population of 118 subjects, the mean age was 66 (standard deviation, range: 8, 50 to 79) years and $52 \%$ were female. Table 1 shows that patients in the $\mathrm{AD}$ group were older, more often female, and more often $A P O E-\varepsilon 4$ carriers than patients in the control group. They also had less hyperlipidemia and higher blood pressure levels. CSF A $\beta$ levels were lower in AD patients, and CSF tau and ptau levels were higher in AD patients. Further, all ACE measures were lower in patients with $\mathrm{AD}$ compared with patients in the control group (Table 1). The Pearson correlation coefficient between CSF ACE protein level and CSF ACE activity was $0.26(P=0.005)$, between serum ACE protein level and 
serum ACE activity was $0.28(P=0.002)$, between CSF and serum ACE protein levels was $0.54(P<0.001)$, and between CSF and serum ACE activity levels was $0.07(P=0.494)$. The correlation between tau and $\mathrm{A} \beta$ was $-0.43(P<0.001)$ and between ptau and $A \beta$ was $-0.41(P=0.0004)$. Further, $A P O E-\varepsilon 4$ carriers had significantly lower $\mathrm{A} \beta(\mathrm{B}=-0.32)$, and significantly higher tau $(B=0.50)$ and ptau levels $(\mathrm{B}=0.31) ; P<0.001$ for all.

\section{Cerebrospinal fluid ACE measures and cerebrospinal fluid biomarkers}

In the total population, higher CSF ACE protein level was independently associated with higher CSF $A \beta$, tau and ptau levels (Table 2). When stratified by study group, the associations between higher CSF ACE protein levels and higher CSF $A \beta$, tau and ptau were present in the control group and the $\mathrm{AD}$ group, although significance was lost for CSF tau in the control group (Figures 1, 2 and 3).

Higher CSF ACE activity was also marginally associated with higher CSF A $\beta$ levels, but not with CSF tau or ptau levels (Table 2). When stratified by study groups, the association was particularly present in the AD group (Figure 1).

Serum ACE measures and cerebrospinal fluid biomarkers In the total population, higher serum ACE protein level was associated with higher CSF A $\beta$ (borderline significance), but not with CSF tau or ptau levels (Table 2). When stratified by study groups, the association was more evident in the control group and not in the AD group: mean differences (95\% confidence interval) between the highest and lowest serum ACE protein tertiles were 193 (47; 340) and $44(-62 ; 151)$, respectively (Model 2$)$.

Serum ACE activity was not associated with higher CSF A $\beta$, tau or ptau levels (Table 2).

\section{Discussion}

The main findings of this study are that lower CSF ACE protein levels, and to a lesser extent serum ACE protein and CSF ACE activity levels, were associated with lower CSF $A \beta$ levels, indicating increased $A \beta$ accumulation in the brain. Surprisingly, lower CSF ACE protein levels were associated with lower CSF tau and ptau levels, indicating less brain tau pathology. These associations were found in both control and AD patients and were independent of age, sex, $A P O E$ genotype, and vascular risk factors. Further, CSF and serum ACE protein and activity levels were lower in AD patients compared with controls.

To our knowledge, this is the first study that linked direct measures of ACE activity to the CSF AD biomarkers $A \beta$, tau, and ptau. Our results on the association of CSF ACE protein level and CSF A $\beta$ are in line with studies that showed an association between the $A C E$ gene and $\mathrm{A} \beta$. Haplotypes of the $A C E$ gene that were associated with lower ACE levels were related to lower CSF A $\beta[13,14]$, and another study showed that the $I$-allele (indicating lower ACE levels) was associated with slightly more $A \beta$ load in the brain at autopsy [26]. The Rotterdam study examined the $A C E$ genotype in relation to brain atrophy (which is associated with increased brain $A \beta$ plaques) [1], and found that female $I / I$ genotype carriers had smaller hippocampal and

Table 2 Linear regression analyses between CSF and serum ACE measures and log-transformed CSF biomarkers in the total population $(n=118)$

\begin{tabular}{|c|c|c|c|c|}
\hline & Model & $\operatorname{Ln} A \beta 42$ & Ln tau & Ln ptau \\
\hline \multirow[t]{3}{*}{ CSF ACE protein level $^{a}$} & 1 & $0.12(0.05 ; 0.19)^{* *}$ & $0.10(-0.01 ; 0.22)$ & $0.14(0.05 ; 0.22)^{* *}$ \\
\hline & 2 & $0.09(0.04 ; 0.15)^{* *}$ & $0.15(0.06 ; 0.25)^{* *}$ & $0.17(0.10 ; 0.25)^{* *}$ \\
\hline & 3 & $0.11(0.05 ; 0.16)^{* *}$ & $0.16(0.05 ; 0.26)^{* *}$ & $0.19(0.10 ; 0.27)^{* *}$ \\
\hline \multirow[t]{3}{*}{ CSF ACE activity ${ }^{\mathrm{b}}$} & 1 & $0.07(-0.00 ; 0.14)$ & $-0.06(-0.18 ; 0.06)$ & $0.02(-0.07 ; 0.11)$ \\
\hline & 2 & $0.05(-0.00 ; 0.11)$ & $-0.03(-0.13 ; 0.07)$ & $0.04(-0.04 ; 0.12)$ \\
\hline & 3 & $0.06(0.00 ; 0.11)^{*}$ & $-0.04(-0.14 ; 0.06)$ & $0.03(-0.05 ; 0.11)$ \\
\hline \multirow[t]{3}{*}{ Serum ACE protein level ${ }^{c}$} & 1 & $0.09(0.02 ; 0.17)^{*}$ & $-0.09(-0.21 ; 0.03)$ & $-0.02(-0.11 ; 0.07)$ \\
\hline & 2 & $0.06(-0.00 ; 0.12)$ & $-0.03(-0.13 ; 0.07)$ & $0.02(-0.06 ; 0.10)$ \\
\hline & 3 & $0.04(-0.02 ; 0.11)$ & $-0.04(-0.15 ; 0.06)$ & $0.02(-0.06 ; 0.11)$ \\
\hline \multirow[t]{3}{*}{ Serum ACE activity ${ }^{d}$} & 1 & $0.06(-0.01 ; 0.14)$ & $-0.10(-0.22 ; 0.01)$ & $-0.02(-0.10 ; 0.07)$ \\
\hline & 2 & $0.03(-0.03 ; 0.09)$ & $-0.05(-0.15 ; 0.05)$ & $0.02(-0.06 ; 0.10)$ \\
\hline & 3 & $0.02(-0.04 ; 0.08)$ & $-0.06(-0.17 ; 0.05)$ & $0.01(-0.08 ; 0.10)$ \\
\hline
\end{tabular}

Data presented as B (95\% confidence interval). Model 1: unadjusted. Model 2: adjusted for age, sex and study groups. Model 3: additionally adjusted for APOE-£4 genotype, systolic blood pressure, diastolic blood pressure, body mass index, smoking, history of hypercholesterolemia and diabetes mellitus. A $\beta$, amyloid-beta; $\mathrm{ACE}$, angiotensin-converting enzyme; CSF, cerebrospinal fluid; Ln, log-transformed; ptau, tau phosphorylated at threonine 181; RFU, relative fluorescence units;

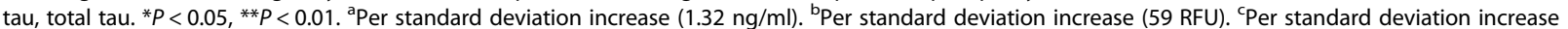
(1.30 ng/ml). ${ }^{\text {d}}$ Per standard deviation increase (133 RFU). 


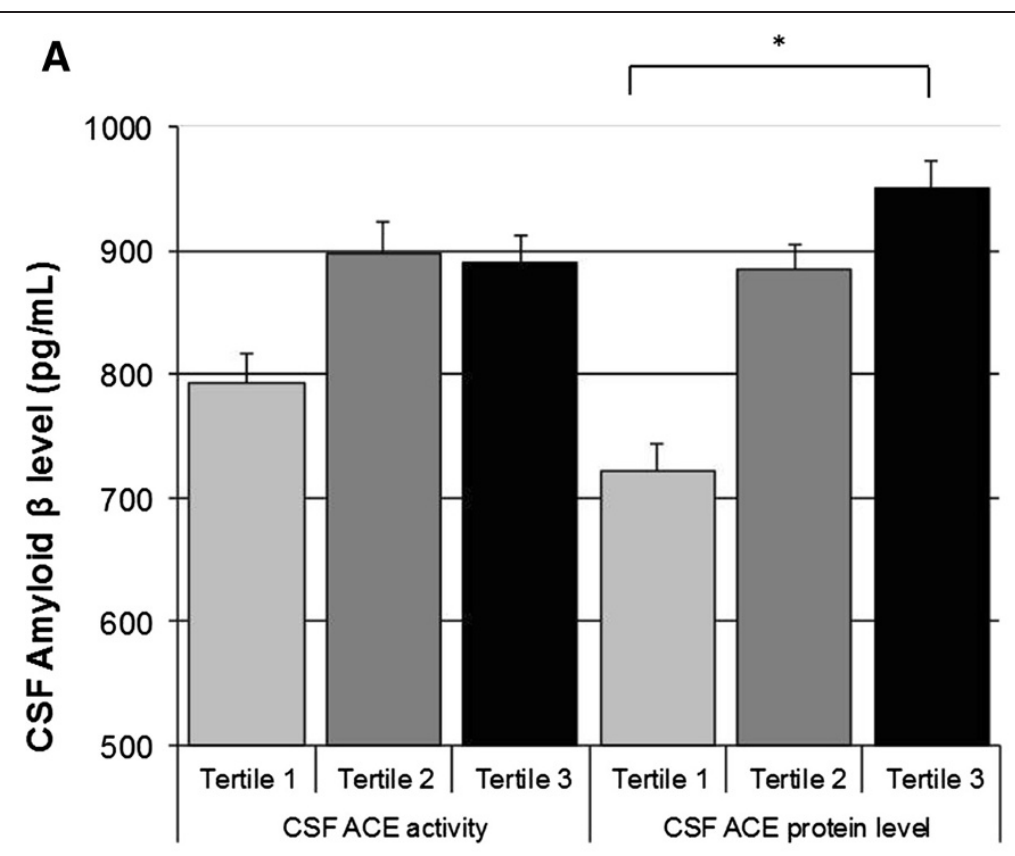

In non-demented group

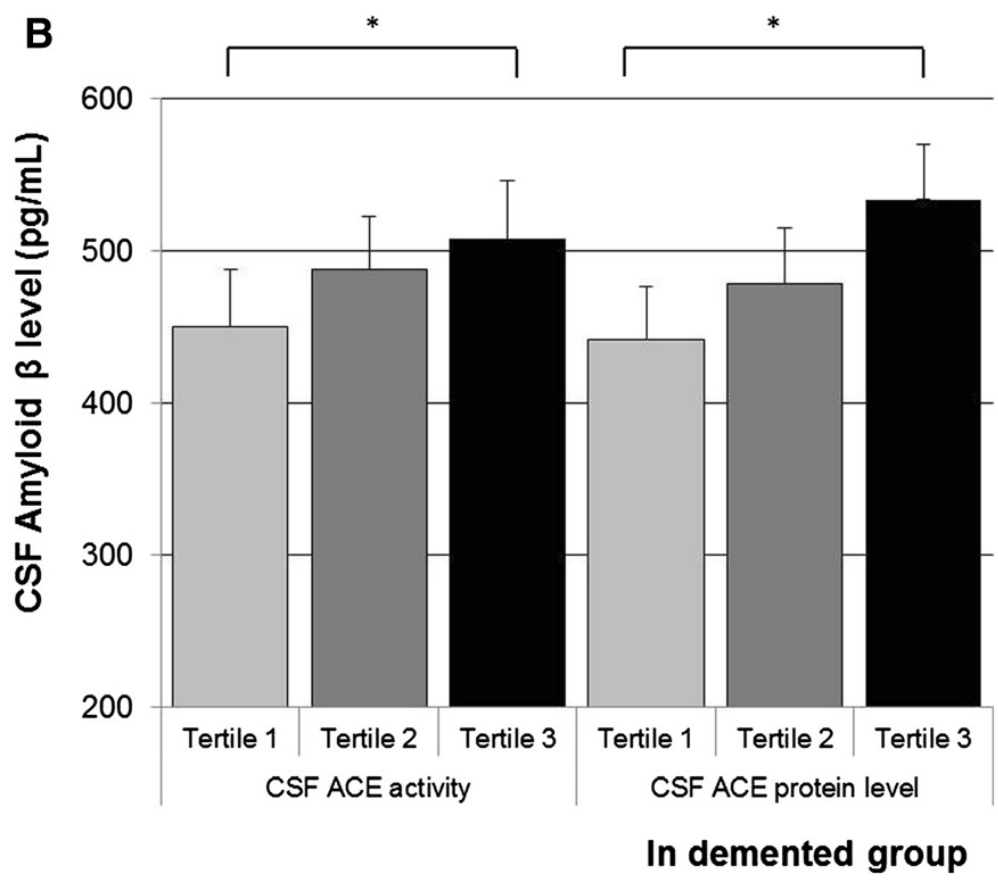

Figure 1 Angiotensin-converting enzyme measures and cerebrospinal fluid amyloid- $\boldsymbol{\beta}_{1-42}$. Mean (standard error) in cerebrospinal fluid (CSF) amyloid- $\beta_{1-42}$ across tertiles of CSF angiotensin-converting enzyme (ACE) activity and CSF ACE protein level, in the control group (A) and the demented group (B). Analyses were adjusted for age and sex. Tertiles for CSF ACE activity: $<121.66 ; 121.66$ to 177.56; $>177.56$ relative fluorescence units. Tertiles for CSF ACE protein level: $<2.95 ; 2.95$ to $3.92 ;>3.92 \mathrm{ng} / \mathrm{ml}$. ${ }^{*} P<0.05$.

amygdalar volumes [27]. Further, we showed in the SMART-MR study that lower serum ACE levels were associated with more progression of cortical brain atrophy [28]. Together, these data suggest that lower ACE could lead to more $A \beta$ accumulation in the brain, reflected by lower CSF $A \beta$, and support previous reports that higher ACE levels, through degradation of $A \beta$, may contribute to less accumulation of $A \beta$ into senile plaques in the brain and subsequently be beneficial for the occurrence of brain atrophy. 


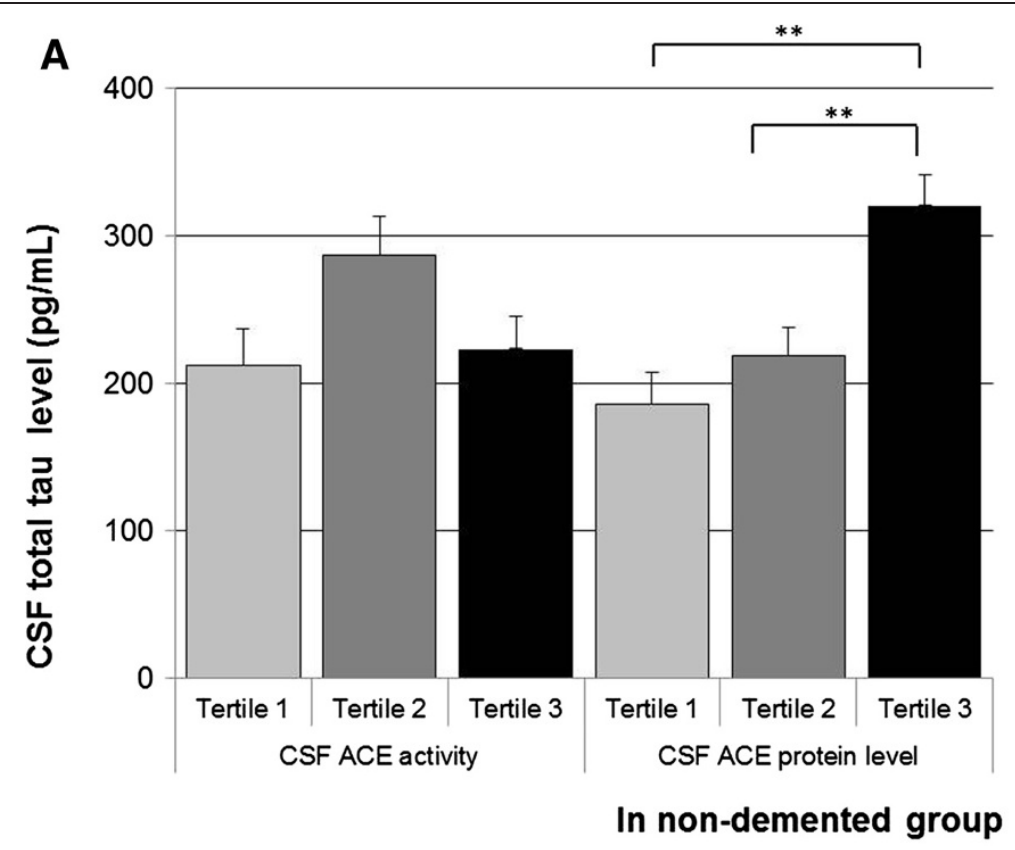

B

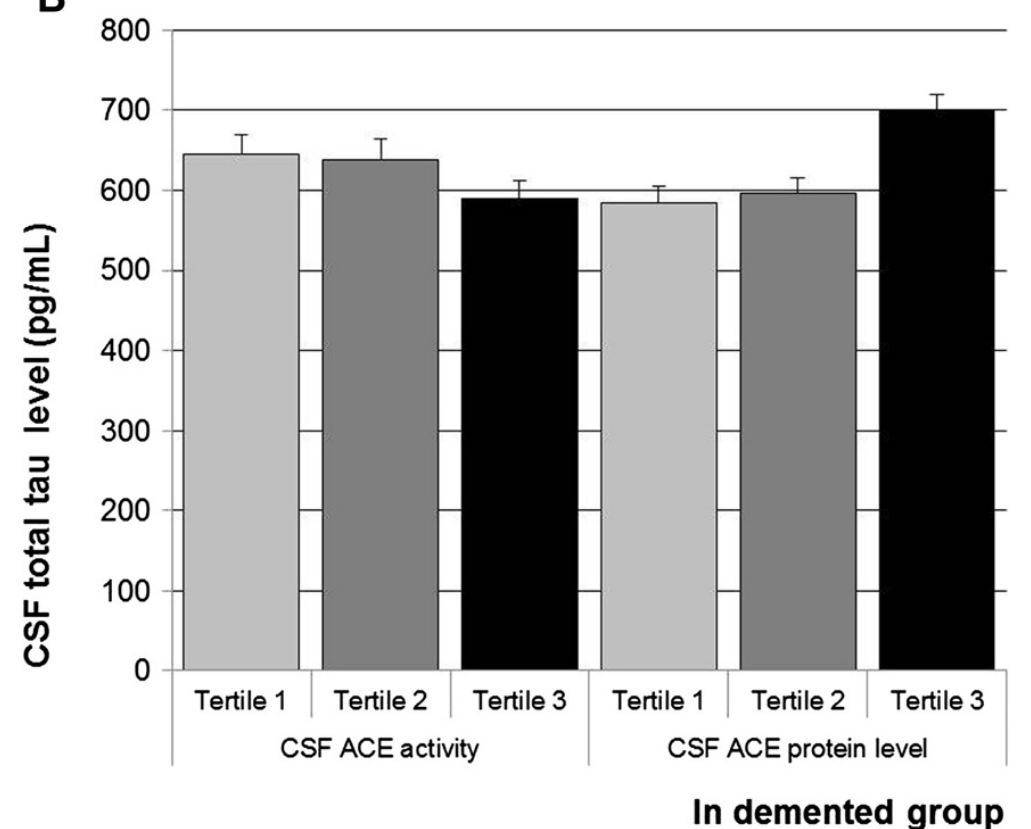

Figure 2 Angiotensin-converting enzyme measures and cerebrospinal fluid total tau. Mean (standard error) in total tau across tertiles of cerebrospinal fluid (CSF) angiotensin-converting enzyme (ACE) activity and CSF ACE protein level, in the control group (A) and demented group (B). Analyses were adjusted for age and sex. Tertiles for CSF ACE activity: $<121.66 ; 121.66$ to 177.56; $>177.56$ relative fluorescence units. Tertiles for CSF ACE protein level: $<2.95 ; 2.95$ to $3.92 ;>3.92 \mathrm{ng} / \mathrm{ml}$. ${ }^{* *} P<0.01$.

Another novel finding was our observation that lower CSF ACE protein level was associated with lower CSF tau and ptau. A previous study relating the $A C E$ genotype to tau load in the brain found no association [26]. The mechanisms explaining the relation between lower ACE and lower CSF tau levels remain largely unknown, although a role for ANGII could be suggested. A recent study showed that central infusion of ANGII in normal rat brains induced tau phosphorylation in a dose-dependent manner via activating glycogen synthase kinase $3 \beta$. Furthermore, this was reversed by co-administration of the ANG II type 1 receptor antagonist, losartan, which is commonly prescribed for the treatment of hypertension [29]. Our findings suggest that higher ACE levels which lead to 


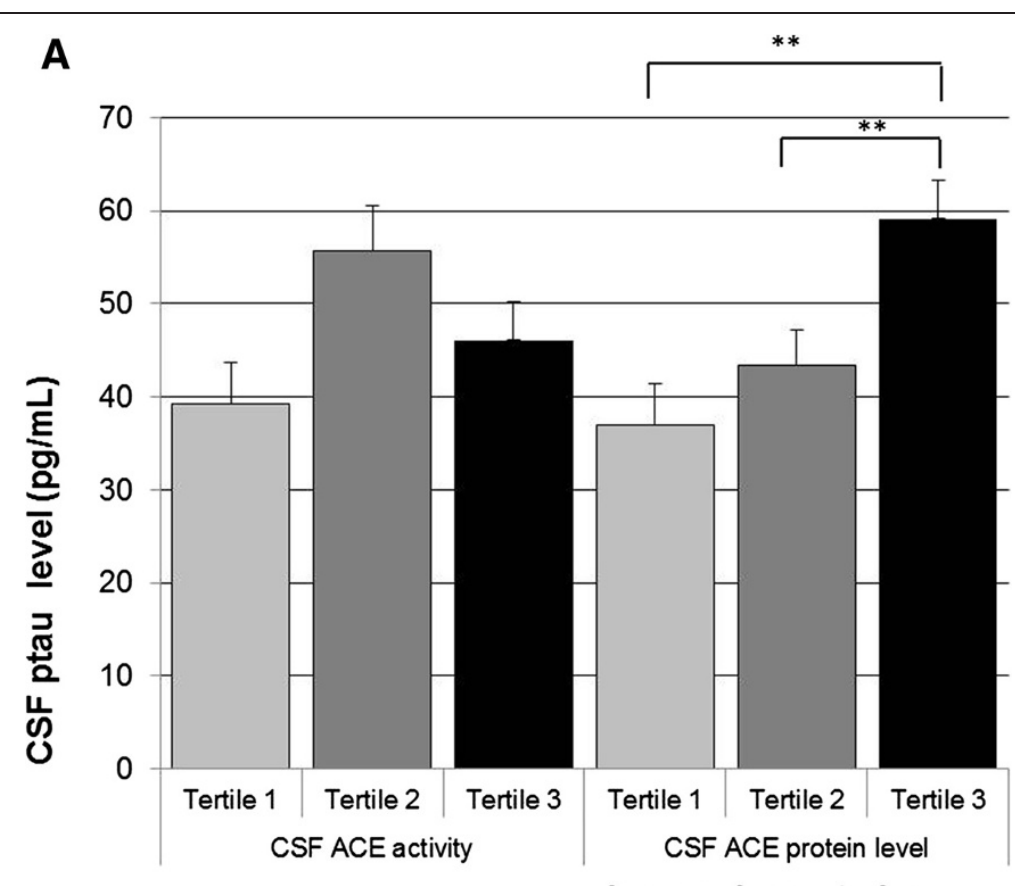

In non-demented group

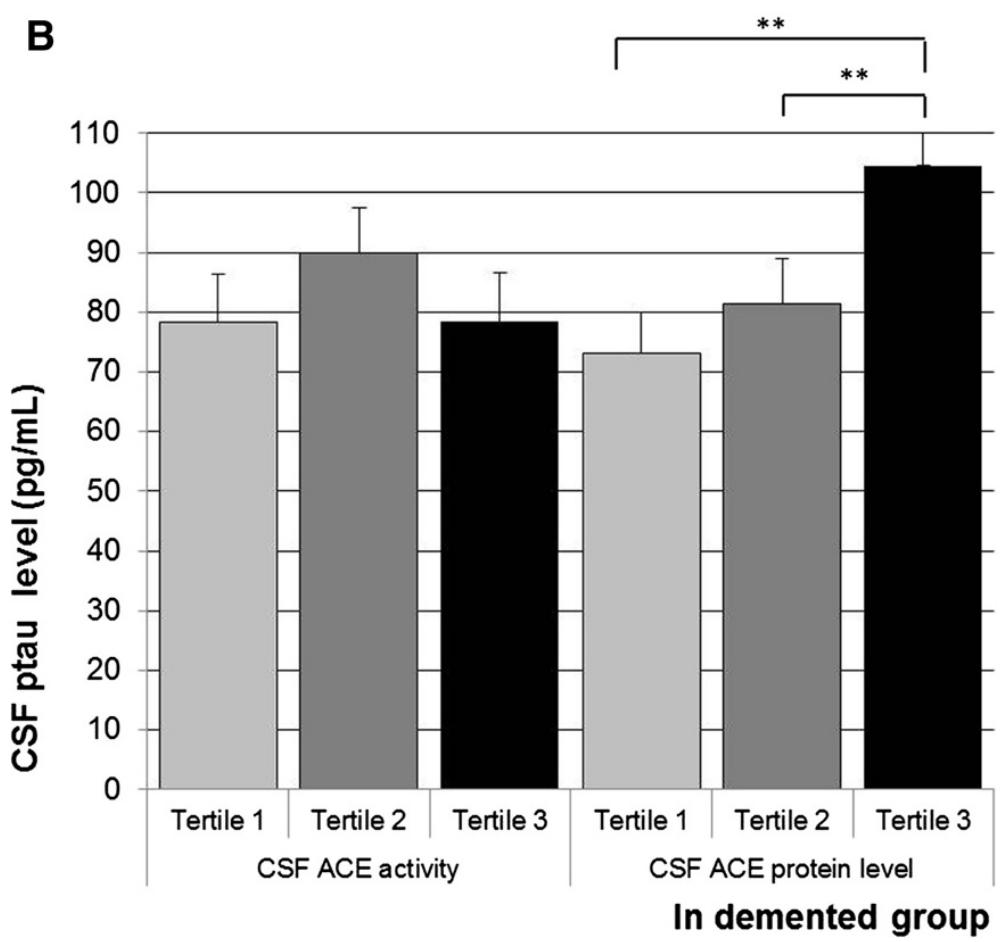

Figure 3 Angiotensin-converting enzyme measures and cerebrospinal fluid phosphorylated tau. Mean (standard error) in phosphorylated tau across tertiles of cerebrospinal fluid (CSF) angiotensin-converting enzyme (ACE) activity and CSF ACE protein level, in the control group (A) and the demented group (B). Analyses were adjusted for age and sex. Tertiles for CSF ACE activity: $<121.66 ; 121.66$ to 177.56; $>177.56$ relative fluorescence units. Tertiles for CSF ACE protein level: $<2.95 ; 2.95$ to $3.92 ;>3.92 \mathrm{ng} / \mathrm{ml}$. ${ }^{* *} P<0.01$.

higher ANGII levels can induce tau pathology in the brain, and in turn result in higher tau levels in the CSF. Coincidentally, and perhaps ironically, while such elevations in ACE may exacerbate tau-related pathology, these same elevations may also have a slightly beneficial mitigating effect in terms of reducing $A \beta$ pathology. Yet no 
association was seen between CSF tau and ptau with CSF ACE activity, which we might expect to be a more biologically meaningful measure of the likely production of ANGII from its precursor ANGI [17].

CSF ACE levels were more strongly associated with AD biomarkers than serum ACE levels. This indicates that CSF ACE, as might be expected, could reflect the activity of the brain RAS, thereby showing stronger associations with brain pathology. Further, ACE protein levels were more strongly associated with $\mathrm{AD}$ biomarkers than ACE activity levels. Whereas protein levels indicate the concentration of ACE in body fluid, activity levels particularly indicate the ANGI to ANGII conversion capacity of the enzyme [22]. One might thus have expected that ACE activity levels in particular would be more indicative of and relevant to $A \beta$ degradation, and would therefore be more strongly associated with CSF A $\beta$. At present we cannot explain this apparent inconsistency; it could be partly related to the $A C E$ genotype although the genetic contribution to ACE levels has only been shown to be relatively modest [12], and unfortunately we did not have information on the $A C E$ genotype in our population so we could not explore this. Another reason might be differential levels of post-translational modification in the various physiological compartments from which the samples were derived. ACE activity, and its proposed conversion of $A \beta$, has been shown previously to be modulated by post-translational modification [30]. In both CSF and serum there may therefore be differential levels of glycosylation that can explain the lower than expected correlations of activity with some of our outcome measures. Miners and colleagues previously showed a trend of divergence between ACE levels and activity in postmortem CSF, but this was not significant and the patterns observed may have been an artifact of postmortem delay where additional changes to the ACE may have occurred post mortem [22]. Yet here remains the possibility that in the brain, from which the levels of $A \beta$, tau and ptau emanate, levels of ACE activity are influenced in a more disease-specific manner by advancing pathology than occurs in the more peripheral compartments we have tested. Indeed, Miners and colleagues have shown in postmortem brain tissue from AD patients that their ACE activity and not their ACE levels are more markedly different than in the control group [22]. Similarly, according to our data there is some support that disease-specific modifications of ACE may be involved since the apparent discrepant findings between ACE levels and activity with respect to CSF $A \beta$ were less marked and seemed to correlate more in the AD group (Figure 1B).

Among the strengths of the current study is the use of CSF ACE measures and CSF biomarkers, which gives the opportunity to examine during life the association between ACE and AD pathology, without potential confounding from postmortem delays. Second, we had paired CSF and serum samples for all of the patients. Finally, all patients were assessed in a standardized way and diagnosed according to commonly used criteria [18].

One of the limitations of our study is the relatively small study population. Yet the interesting results recommend replication in a larger study sample. Another limitation is the cross-sectional design that prohibits conclusions on cause or effect. Similarly, we cannot ascertain whether lower CSF ACE protein and activity levels cause brain A $\beta$ pathology. However, because we found that the associations were also present in the control group, it is reasonable to assume that the downregulation of CSF ACE is not pathology driven, and that lower ACE levels might precede the pathology or alternatively are a general phenomenon associated with neurodegeneration. This hypothesis remains to be further investigated in a larger, longitudinal study.

This study has important clinical implications. If ACE in the brain does prevent $A \beta$ accumulation in living humans, our data support the suggestions that taking ACE inhibitors as antihypertensive drugs, particularly those that can cross the blood-brain barrier, might compromise $A \beta$ degradation [31]. Fortunately, while uncertainty remains on this issue, angiotensin-receptor blockers, which solely target ANG II effects whilst not interfering directly with ACE, could provide an immediate and readily available potential alternative anti-hypertensive therapy for patients at risk for $\mathrm{AD}$ [31-33].

\section{Conclusion}

We found in a memory clinic cohort that lower CSF ACE levels were associated with lower CSF A $\beta$ levels, which suggests more accumulation of $A \beta$ in the brain. This observation lends support to the hypothesis that ACE can degrade $A \beta$, thereby contributing to limiting its accumulation and possibly to the development or rate of progression of $\mathrm{AD}$.

\section{Additional file}

Additional file 1: Is a description of the ACE activity assays.

\begin{abstract}
Abbreviations
Aß: amyloid-beta; ACE: angiotensin-converting enzyme; AD: Alzheimer's disease; ANG: angiotensin; APOE: apolipoprotein E; CSF: cerebrospinal fluid; CV: coefficient of variation; ptau: tau phosphorylated at threonine 181; RAS: renin-angiotensin system; tau: total tau; VUMC: VU University Medical Center.
\end{abstract}

\section{Competing interests}

PGK has undertaken some advisory work for Novartis, which was paid to the University of Bristol. The remaining authors declare that they have no competing interests. 


\section{Authors' contributions}

HMJ, CET, MM, MIG, WMvdF and PS made substantial contributions to the conception and design, and were involved in drafting the manuscript or revising it critically for important intellectual content. ELA, CET, PGK, REJ, HMJ and $\mathrm{MM}$ made substantial contributions to the acquisition of data, or the analysis and interpretation of data. All authors gave final approval of the version to be published.

\section{Acknowledgements}

The authors would like to acknowledge Dr James S Miners (Dementia Research Group, University of Bristol, UK) for his assistance with the development of the CSF and serum ACE assays. Research of the VUMC Alzheimer Center is part of the neurodegeneration research program of the Neuroscience Campus Amsterdam. The VUMC Alzheimer Center is supported by Alzheimer Nederland and Stichting VUMC fonds. The clinical database structure was developed with funding from Stichting Dioraphte. This study was supported by the 'Internationale Stichting Alzheimer Onderzoek' (ISAO: project No. 09502) and 'Alzheimer Nederland' (WE.15-2011-02). The funding sources had no involvement in the writing of this article or in the decision to submit it for publication.

\section{Author details}

AAlzheimer Center \& Department of Neurology, Neuroscience Campus Amsterdam, VU University Medical center, ZKH 4A.35, PO Box 7057, 1007 MB Amsterdam, the Netherlands. ${ }^{2} J u l i u s$ Center for Health Sciences and Primary Care, University Medical Center Utrecht, Utrecht, the Netherlands. ${ }^{3}$ Department of Clinical Chemistry, Neurological Laboratory, VU University Medical Center, Amsterdam, the Netherlands. ${ }^{4}$ Dementia Research Group, Institute of Clinical Neurosciences, School of Clinical Sciences, University of Bristol, Frenchay Hospital, Bristol BS16 1LE, UK. ${ }^{5}$ Department of Gerontology and Geriatric Medicine, Leiden University Medical Center, Leiden, The Netherlands.

Received: 19 July 2013 Accepted: 8 April 2014

Published: 15 May 2014

\section{References}

1. Ballard C, Gauthier S, Corbett A, Brayne C, Aarsland D, Jones E: Alzheimer's disease. Lancet 2011, 377:1019-1031.

2. Rigat B, Hubert C, Henc-Gelas F, Cambien F, Corvol P, Soubrier F: An insertion/deletion polymorphism in the angiotensin I-converting enzyme gene accounting for half the variance of serum enzyme levels. J Clin Invest 1990, 86:1343-1346.

3. Lehmann DJ, Cortina-Borja M, Warden DR, Smith AD, Sleegers K, Prince JA, van Duijn CM, Kehoe PG: Large meta-analysis establishes the ACE insertion-deletion polymorphism as a marker of Alzheimer's disease. Am J Epidemiol 2005, 162:305-317.

4. Elkins JS, Douglas VC, Johnston SC: Alzheimer disease risk and genetic variation in ACE: a meta-analysis. Neurology 2004, 62:363-368.

5. Carrasquillo MM, Zou F, Pankratz VS, Wilcox SL, Ma L, Walker LP, Younkin SG, Younkin CS, Younkin LH, Bisceglio GD, Ertekin-Taner N, Crook JE, Dickson DW, Petersen RC, Graff-Radford NR, Younkin SG: Genetic variation in $\mathrm{PCDH} 11 \mathrm{X}$ is associated with susceptibility to late-onset Alzheimer's disease. Nat Genet 2009, 41:192-198.

6. Li H, Wetten S, Li L, St Jean PL, Upmanyu R, Surh L, Hosford D, Barnes MR, Briley JD, Borrie M, Coletta N, Delisle R, Dhalla D, Ehm MG, Feldman HH, Fornazzari L, Gauthier S, Goodgame N, Guzman D, Hammond S, Hollingworth P, Hsiung GY, Johnson J, Kelly DD, Keren R, Kertesz A, King KS, Lovestone S, Loy-Englisch I, Matthews PM, et al: Candidate single-nucleotide polymorphisms from a genomewide association study of Alzheimer disease. Arch Neurol 2008, 65:45-53.

7. Belbin O, Brown K, Shi H, Medway C, Abraham R, Passmore P, Mann D, Smith AD, Holmes C, McGuinness B, Craig D, Warden D, Heun R, Kölsch H, Love S, Kalsheker N, Williams J, Owen MJ, Carresquillo M, Younkin S, Morgan K, Kehoe PG: A multi-center study of ACE and the risk of late-onset Alzheimer's disease. J Alzheimers Dis 2011, 24:587-597.

8. Hemming ML, Selkoe DJ: Amyloid beta-protein is degraded by cellular angiotensin-converting enzyme (ACE) and elevated by an ACE inhibitor. J Biol Chem 2005, 280:37644-37650.

9. Hu J, Igarashi $\mathrm{A}$, Kamata $\mathrm{M}$, Nakagawa $\mathrm{H}$ : Angiotensin-converting enzyme degrades Alzheimer amyloid beta-peptide (A $\beta$ ); retards $A \beta$ aggregation, deposition, fibril formation; and inhibits cytotoxicity. J Biol Chem 2001, 276:47863-47868.

10. Oba R, Igarashi A, Kamata M, Nagata K, Takano S, Nakagawa H: The N-terminal active centre of human angiotensin-converting enzyme degrades Alzheimer amyloid beta-peptide. Eur J Neurosci 2005, 21:733-740.

11. Kehoe PG, Miners S, Love S: Angiotensins in Alzheimer's disease - friend or foe? Trends Neurosci 2009, 32:619-628.

12. Kehoe PG, Passmore PA: The renin-angiotensin system and antihypertensive drugs in Alzheimer's disease: current standing of the angiotensin hypothesis? J Alzheimers Dis 2012, 30:S251-S268.

13. Kehoe PG, Katzov H, Feuk L, Bennet AM, Johansson B, Wiman B, de Faire U, Cairns NJ, Wilcock GK, Brookes AJ, Blennow K, Prince JA: Haplotypes extending across ACE are associated with Alzheimer's disease. Hum Mol Genet 2003, 12:859-867.

14. Kauwe JS, Wang J, Mayo K, Morris JC, Fagan AM, Holtzman DM, Goate AM Alzheimer's disease risk variants show association with cerebrospinal fluid amyloid beta. Neurogenetics 2009, 10:13-17.

15. Wharton W, Stein JH, Korcarz C, Sachs J, Olson SR, Zetterberg H, Dowling M, Ye S, Gleason CE, Underbakke G, Jacobson LE, Johnson LE, Johnson SC, Sager MA, Asthana S, Carlsson CM: The effects of ramipril in individuals at risk for alzheimer's disease: results of a pilot clinical trial. J Alzheimers Dis 2012, 32:147-156.

16. Gillies LK, Werstiuk ES, Lee RM: Cross-over study comparing effects of treatment with an angiotensin converting enzyme inhibitor and an angiotensin II type 1 receptor antagonist on cardiovascular changes in hypertension. J Hypertens 1998, 16:477-486

17. Wright JW, Harding JW: Brain renin-angiotensin - a new look at an old system. Prog Neurobiol 2011, 95:49-67.

18. McKhann G, Drachman D, Folstein M, Katzman R, Price D, Stadlan EM: Clinical diagnosis of Alzheimer's disease: report of the NINCDS-ADRDA Work Group under the auspices of Department of Health and Human Services Task Force on Alzheimer's Disease. Neurology 1984, 34:939-944.

19. Jochemsen HM, Geerlings MI, Visseren FL, Algra A, van der Graaf Y, Muller M: Serum angiotensin-converting enzyme and recurrent vascular events. The SMART-MR study. Atherosclerosis 2012, 224:486-491.

20. Teunissen CE, Petzold A, Bennett JL, Berven FS, Brundin L, Comabella M, Franciotta D, Frederiksen JL, Fleming JO, Furlan R, Hintzen RQ, Hughes SG, Johnson MH, Krasulova E, Kuhle J, Magnone MC, Raida C, Rejdak K, Schmidt HK, van Pesch V, Waubant E, Wolf C, Giovannoni G, Hemmer B, Tumani H, Deisenhammer F: A consensus protocol for the standardization of cerebrospinal fluid collection and biobanking. Neurology 2009, 73:1914-1922.

21. Mulder C, Verwey NA, van der Flier WM, Bouwman FH, Kok A, van Elk EJ, Scheltens P, Blankenstein MA: Amyloid-beta(1-42), total tau, and phosphorylated tau as cerebrospinal fluid biomarkers for the diagnosis of Alzheimer disease. Clin Chem 2010, 56:248-253.

22. Miners $\mathrm{S}$, Ashby E, Baig S, Harrison R, Tayler H, Speedy E, Prince JA, Love $\mathrm{S}$, Kehoe PG: Angiotensin-converting enzyme levels and activity in Alzheimer's disease: differences in brain and CSF ACE and association with ACE1 genotypes. Am J Trans/ Res 2009, 1:163-177.

23. Miners JS, Ashby E, Van Helmond Z, Chalmers KA, Palmer LE, Love S, Kehoe PG: Angiotensin-converting enzyme (ACE) levels and activity in Alzheimer's disease, and relationship of perivascular ACE-1 to cerebral amyloid angiopathy. Neuropathol Appl Neurobiol 2008, 34:181-193.

24. Donders AR, van der Heijden GJ, Stijnen T, Moons KG: Review: a gentle introduction to imputation of missing values. J Clin Epidemiol 2006, 59:1087-1091

25. Van der Heijden GJ, Donders AR, Stijnen T, Moons KG: Imputation of missing values is superior to complete case analysis and the missing-indicator method in multivariable diagnostic research: a clinical example. J Clin Epidemiol 2006, 59:1102-1109.

26. Lendon CL, Thaker U, Harris JM, McDonagh AM, Lambert JC, Chartier-Harlin MC Iwatsubo T, Pickering-Brown SM, Mann DM: The angiotensin 1-converting enzyme insertion (I)/deletion (D) polymorphism does not influence the extent of amyloid or tau pathology in patients with sporadic Alzheimer's disease. Neurosci Lett 2002, 328:314-318.

27. Sleegers K, den Heijer T, van Dijk EJ, Hofman A, Bertoli-Avella AM, Koudstaal PJ, Breteler MM, van Duijn CM: ACE gene is associated with Alzheimer's disease and atrophy of hippocampus and amygdala. Neurobiol Aging 2005, 26:1153-1159. 
28. Jochemsen HM, Geerlings MI, Grool AM, Vincken KL, Mali WP, van der Graaf $Y$, Muller M: Angiotensin-converting enzyme and progression of white matter lesions and brain atrophy - the SMART-MR study. J Alzheimers Dis 2012, 29:39-49.

29. Tian M, Zhu D, Xie W, Shi J: Central angiotensin II-induced Alzheimer-like tau phosphorylation in normal rat brains. FEBS Lett 2012, 586:3737-3745.

30. Zou K, Maeda T, Watanabe A, Liu J, Liu S, Oba R, Satoh Y, Komano H, Michikawa M: A 342 -to-A $\beta 40$ - and angiotensin-converting activities in different domains of angiotensin-converting enzyme. J Biol Chem 2009, 284:31914-31920

31. Kehoe PG, Wilcock GK: Is inhibition of the renin-angiotensin system a new treatment option for Alzheimer's disease? Lancet Neurol 2007, 6:373-378.

32. Kehoe PG, Davies NM, Martin RM, Ben Shlomo Y: Associations of angiotensin targeting antihypertensive drugs with mortality and hospitalization in primary care patients with dementia. J Alzheimers Dis 2012, 33:999-1008

33. Li NC, Lee A, Whitmer RA, Kivipelto M, Lawler E, Kazis LE, Wolozin B: Use of angiotensin receptor blockers and risk of dementia in a predominantly male population: prospective cohort analysis. BMJ 2010, 340:b5465. 10.1136/bmj.b5465.:b5465.

doi:10.1186/alzrt257

Cite this article as: Jochemsen et al:: The association of angiotensinconverting enzyme with biomarkers for Alzheimer's disease. Alzheimer's Research \& Therapy 2014 6:27.

\section{Submit your next manuscript to BioMed Central and take full advantage of:}

- Convenient online submission

- Thorough peer review

- No space constraints or color figure charges

- Immediate publication on acceptance

- Inclusion in PubMed, CAS, Scopus and Google Scholar

- Research which is freely available for redistribution 